\title{
RADIOCARBON DATING OF LARGE HOLOCENE VOLCANIC EVENTS WITHIN SOUTH KAMCHATKA (RUSSIAN FAR EAST)
}

\author{
Natalia E Zaretskaya ${ }^{1,2} \bullet$ Vera V Ponomareva $^{3} \bullet$ Leopold D Sulerzhitsky $^{1}$
}

\begin{abstract}
Radiocarbon dating is widely used when studying recent volcanic activity in the Kamchatka Peninsula due to the abundance of organic matter that is associated with the volcanic deposits. Here, we present the results of ${ }^{14} \mathrm{C}$ dating of major volcanic events within the active South Kamchatka volcanic zone. South Kamchatka includes 8 recently active volcanic centers (stratovolcanoes, calderas, and large craters) that have been erupting during the Holocene. Their tephras represent useful markers for both the southern part of the peninsula and the Northern Kurile Islands. Since these marker tephra layers facilitate stratigraphic and tephrochronological studies in this area, it was important to determine their ages. We have obtained 73 new individual ${ }^{14} \mathrm{C}$ dates on paleosol, peat, charcoal, and wood associated with the marker tephra layers, then complemented these data with 37 earlier published dates and analyzed the resulting data set. We selected the reliable dates and then obtained average ${ }^{14} \mathrm{C}$ ages of marker tephra layers. The details of these procedures, as well as brief descriptions of South Kamchatka Holocene eruptions and their tephra beds, are presented in the paper.
\end{abstract}

\section{INTRODUCTION}

Radiocarbon dating is widely used when studying recent volcanic activity in the Kamchatka Peninsula, northwestern Pacific region (Sulerzhitsky 1971; Braitseva et al. 1993, 1995, 1997; Zaretskaia et al. 2001a,b). Here, it has proved to work better for the late Pleistocene-Holocene deposits than other methods of isotope dating (e.g. ${ }^{40} \mathrm{Ar} /{ }^{39} \mathrm{Ar}, \mathrm{K} / \mathrm{Ar}, \mathrm{U} / \mathrm{Th}$ ) due to the abundance and high productivity of organic matter associated with the volcanic deposits of this age, and the lack of $\mathrm{K}$ in the young volcanic rocks. In this paper, we describe ${ }^{14} \mathrm{C}$ dating of major Holocene volcanic events within the active South Kamchatka volcanic zone. We provide 73 new and 37 earlier published dates on the organic matter associated with the Holocene tephra layers (Table 1); discuss the validity and significance of the dates, which depend on the characteristics of the dated material; and finally, present a list of dated key-marker tephra layers in South Kamchatka. These tephra layers document the largest explosive eruptions in this region.

South Kamchatka (Figures 1 and 2) hosts a number of volcanic centers that have produced large explosive eruptions during the Holocene. These are, from north to south: the Chasha Crater, the Baranii Amphitheater Crater at the foot of Opala Volcano, and Khodutkinsky Crater; the Ksudach caldera massif with a young stratovolcano, Stübel Cone, inside; the Zheltovsky and Iliinsky volcanoes; the large Kurile Lake caldera; and the Dikii Greben' and Kambalny volcanoes. The largest Holocene explosive eruption of the region (coded $\mathrm{KO}$ ) has resulted in the formation of the Kurile Lake caldera. The eruption took place $\sim 7.6 \mathrm{kyr}$ BP (Zaretskaia et al. 2001b). It has a conservatively estimated tephra volume of $140-170 \mathrm{~km}^{3}$, making it the largest Holocene eruption in the Kurile-Kamchatka volcanic arc and ranking it among Earth's largest Holocene explosive eruptions (Ponomareva et al. 2004). The KO tephra was dispersed over an area of $>3$ million $\mathrm{km}^{2}$, mostly in a northwest direction (Figure 1). It is a valuable stratigraphic marker for southern Kamchatka, the Sea of Okhotsk, and a large part of the Asian mainland, where it has been identified as a 6- to $0.1-\mathrm{cm}$-thick layer in terrestrial and lake sediments, $1000-1700 \mathrm{~km}$ from the source (Anderson et al. 1998; Gorbarenko et al. 2002). The KO ignimbrite is $140 \mathrm{~m}$ thick near the lake and extends to the Sea of Okhotsk and the Pacific Ocean on either side of the peninsula. The KO tephra is an important benchmark for the Holocene stratigraphy of South Kamchatka.

\footnotetext{
${ }^{1}$ Geological Institute of the Russian Academy of Sciences, Moscow, Russia.

2Corresponding author. Email: tumskoy@comtv.ru; n_zaretskaya@inbox.ru.

${ }^{3}$ Institute of Volcanology and Seismology, Petropavlovsk-Kamchatsky, Russia.
} 


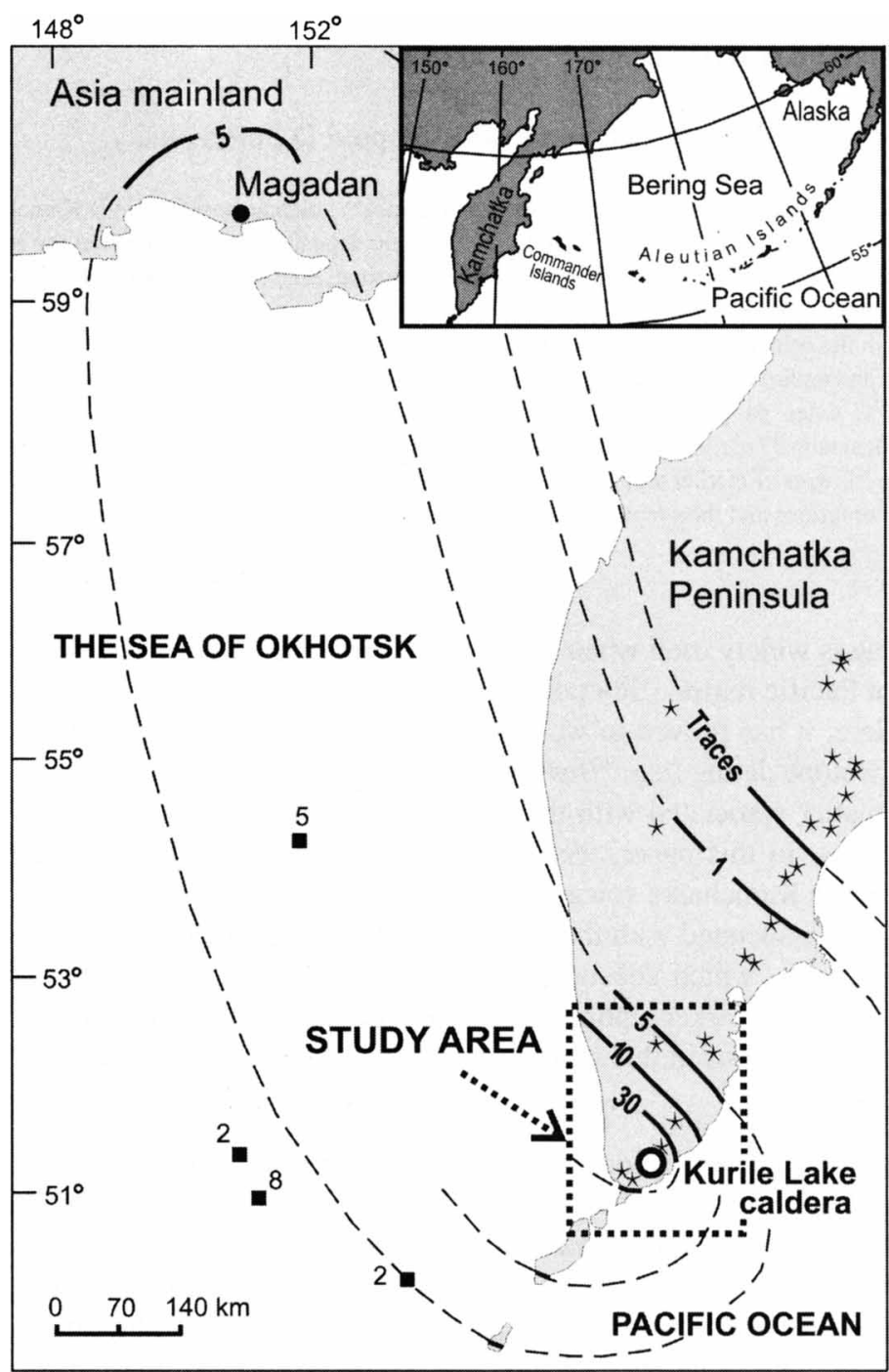

\section{KO tephra dispersal}

- 1- Isopachs based on ground measurements (thickness in $\mathrm{cm}$ )

.... Presumed isopachs
2. Sea cores and thickness of $\mathrm{KO}$ ash in $\mathrm{cm}$

$\star \quad$ Holocene volcanoes

Figure 1 Location of the study area and dispersal of the largest South Kamchatka tephra, associated with the Kurile Lake caldera-forming eruption. The inset shows the location of Kamchatka within the northern Pacific region.

Three other tephras $\left(\mathrm{KS}_{1}\right.$ and $\mathrm{KS}_{2}$ from Ksudach caldera and OP from Baranii Amphitheater Crater at the foot of Opala Volcano) yielded volumes of $9-19 \mathrm{~km}^{3}$ and also covered large territories (Melekestsev et al. 1996b; Braitseva et al. 1997; Volynets et al. 1999). These tephra layers were dated earlier based on numerous individual ${ }^{14} \mathrm{C}$ dates (Braitseva et al. 1995, 1997). 

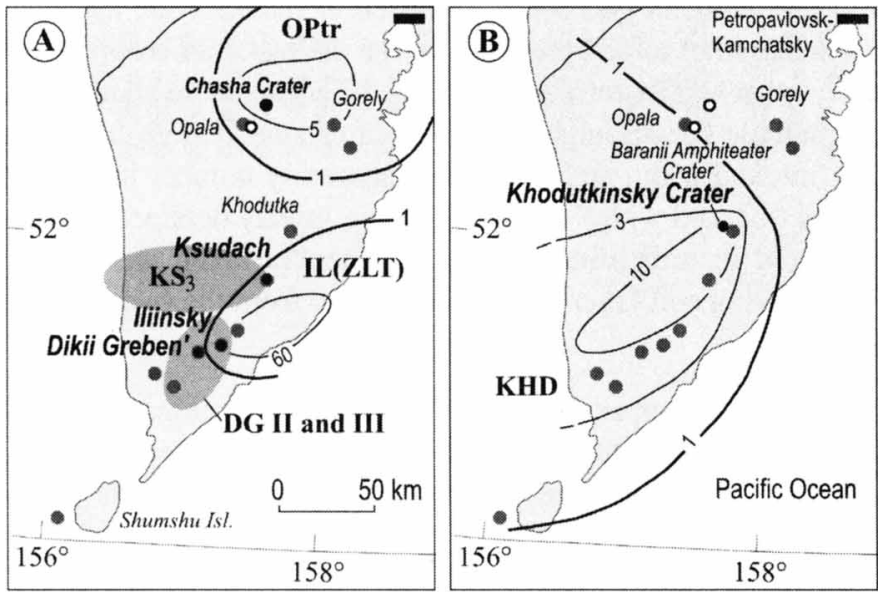

- Active volcanoes

- Large craters

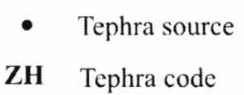

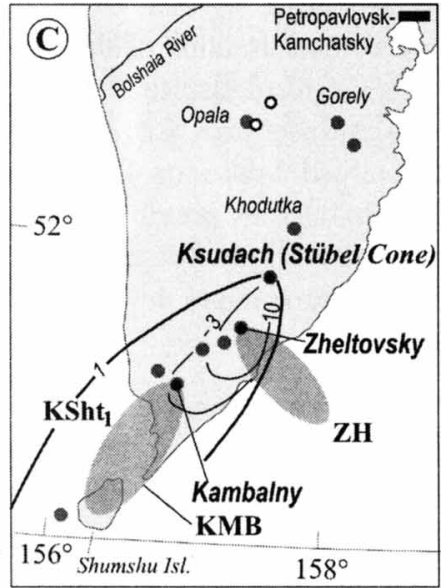

Tephra isopachs (thickness in $\mathrm{cm}$ )

Dispersal of local marker tephras

Figure 2 Dispersal of the key-marker tephra layers in South Kamchatka. For codes of tephra layers, see the text and Table 2. $\mathrm{OP}_{\mathrm{tr}}$ isopachs are modified from Dirksen et al. (2002); other isopachs and areas of tephra dispersal are based on the authors' field data.

Ten more tephra layers with smaller volumes also play an important role in the Holocene stratigraphy in the southern part of the peninsula and Northern Kurile Islands and record large explosive eruptions of local volcanoes (Table 2). Five of those $\left(\mathrm{KS}_{3}, \mathrm{IL}[\mathrm{ZLT}], \mathrm{OP}_{\mathrm{tr}}, \mathrm{KHD}\right.$, and $\left.\mathrm{KSt}_{1}\right)$ have been dated and briefly described earlier (Braitseva et al. 1997). We evaluate published dates, provide new ones, and refine the ages of these volcanic events. In addition, we have identified and dated 5 more marker tephra layers (DG II, DG III, $\mathrm{KMB}_{\mathrm{phr}}, \mathrm{ZH}$, and $\mathrm{ZH}_{1}$ ).

\section{METHODS}

\section{Radiocarbon Dating: Field Sampling, Pretreatment, and Date Selection}

Tephra layers are widespread in the Kamchatka Peninsula, which hosts more than 30 active volcanoes. Holocene tephra layers separated by soils, sandy loams, or peats form the soil-pyroclastic cover that blankets most of Kamchatka. This cover is a few tens of centimeters thick in areas far from the active volcanoes and increases up to several meters at their source. The cover provides a continuous record of the explosive eruptions during the Holocene, while earlier tephra layers in Kamchatka were mostly destroyed during Late Pleistocene glaciation and occur as isolated beds.

We performed the ${ }^{14} \mathrm{C}$ dating of various organic matter (paleosols, sandy loams, peat, charcoal, and wood) associated with the marker tephra layers. The samples were collected in different depositional environments in South Kamchatka, at different distances from the eruptive sources.

In South Kamchatka, paleosols and organic-poor sandy loams, buried by tephra layers, are 1-15 cm thick and have no developed soil profile. They are composed of redeposited ash variably enriched in organic matter. For ${ }^{14} \mathrm{C}$ dating, we collected bulk samples of paleosols and sandy loams above and beneath tephra layers. Normally, we tried to collect thin $(\sim 1 \mathrm{~cm})$ layers of organic-repleted soils, but sometimes we had to collect thick $(3-5 \mathrm{~cm})$ layers of sandy loams to obtain a sufficient quantity of material for dating. 
The standard acid-alkali-acid (AAA) pretreatment procedure was used to measure the age of the alkali-soluble fraction of the soils. In an attempt to add precision to the dating of an eruption (particularly while dating thick soil layers), we generally retrieved and dated 2 consecutive alkali extractions (cold and then hot) from 1 bulk sample (Braitseva et al. 1993; Zaretskaia et al. 2001a); thus, we obtained 2 dates on 1 soil sample (marked with and $_{\text {II }}$ after the laboratory number in Table 1). Ages obtained by previous investigators (marked with * in Table 1) were mostly obtained on material from a single hot alkaline extraction. In estimating the age of a tephra layer, we normally selected the younger date from the underlying soil layer and the older date from the overlying soil layer.

Some dates on a long-lived paleosol, even on its upper part, may yield any ages within the limits of this paleosol formation interval and thus be significantly older than the age of the overlying tephra (e.g. Ponomareva et al. 2001). For this reason, dates were obtained on successive alkaline extractions from several samples in order to determine reproducibility.

Peat bogs, enclosing volcanic tephra layers and lahar (volcanic mudflow) deposits, are widespread in Kamchatka. Peat seems useful for dating explosive eruptions because even the thinnest ("onegrain-thick") tephra layers are clearly recoverable from the peat. Peat bogs are continuously growing systems with organic matter accumulating during the Holocene. In most cases, the deposition of a thin layer of tephra does not interrupt peat accumulation (Hotes et al. 2004), so by dating material from above and beneath peat layers, we can constrain more effectively the ages of marker tephras.

We collected bulk peat samples from above and beneath tephra layers. Once again, the $A-A_{\text {cold }}{ }^{-} A_{\text {hot }}{ }^{-}$ A procedure was utilized and 2 subsamples (derived from the cold and hot alkaline extractions) were dated from each bulk sample (i.e. a procedure similar to the paleosols pretreatment). In cases where plant remnants were well preserved, we recovered both the cold extraction and the alkali-insoluble fraction. For small samples, we applied a single hot alkaline extraction and dated 1 sample. Most of the previously published dates were measured on material treated using a single hot alkaline extraction.

In Kamchatka, dates of bulk peat may sometimes result in younger ages than expected due to the contamination of the peat layer with young roots coming from the upper layers of the bog (Zaretskaia et al. 2001a). We therefore analyzed the plant composition of each peat sample and then studied all determined species in a herbarium (Institute of Botany, Russian Academy of Sciences, St. Petersburg) to understand the reasons for this. We found several sedge species with very long roots penetrating through tephra and peat layers into older stratigraphic levels. These are Carex cryptocarpa C.A. Mey, C. vesicata Meinsh., C. monile Tuckerm.; and $C$. middendorffii Fr. Schmidt. The length of the sedge roots can exceed $1 \mathrm{~m}$ (Alexeev 1996), and, according to our field observations, they can penetrate through $<7-\mathrm{cm}$-thick layers of fine-grained and $<2-\mathrm{cm}$-thick layers of coarse ash. Individual peat samples may contain up to $90 \%$ of these long-root sedges. When analyzing the plant composition of a bulk peat sample, one cannot determine whether fragments of these long-root sedges belong to this particular peat horizon or have penetrated from the younger layers. Thus, the presence of these sedges in a peat sample is a good indicator that the sample may produce an age younger than expected based on its stratigraphic position. We concluded that sample contamination by younger roots might take place in these cases (Zaretskaia and Uspenskaia 2001; Zaretskaia et al. 2001a). Other Cyperaceous plants (such as Carex lasiocarpa, C. pauciflora Liqhtf., and other sedges), rootless mosses (Sphagnum or Bryales), or other grasses (Calamagrostis langsdorffii, Equisetum fluviatile L., etc.) generally do not influence the ${ }^{14} \mathrm{C}$ age of a bulk peat sample. With this in mind, we have determined plant composition for each of the peat samples dated in this study (Table 1). 


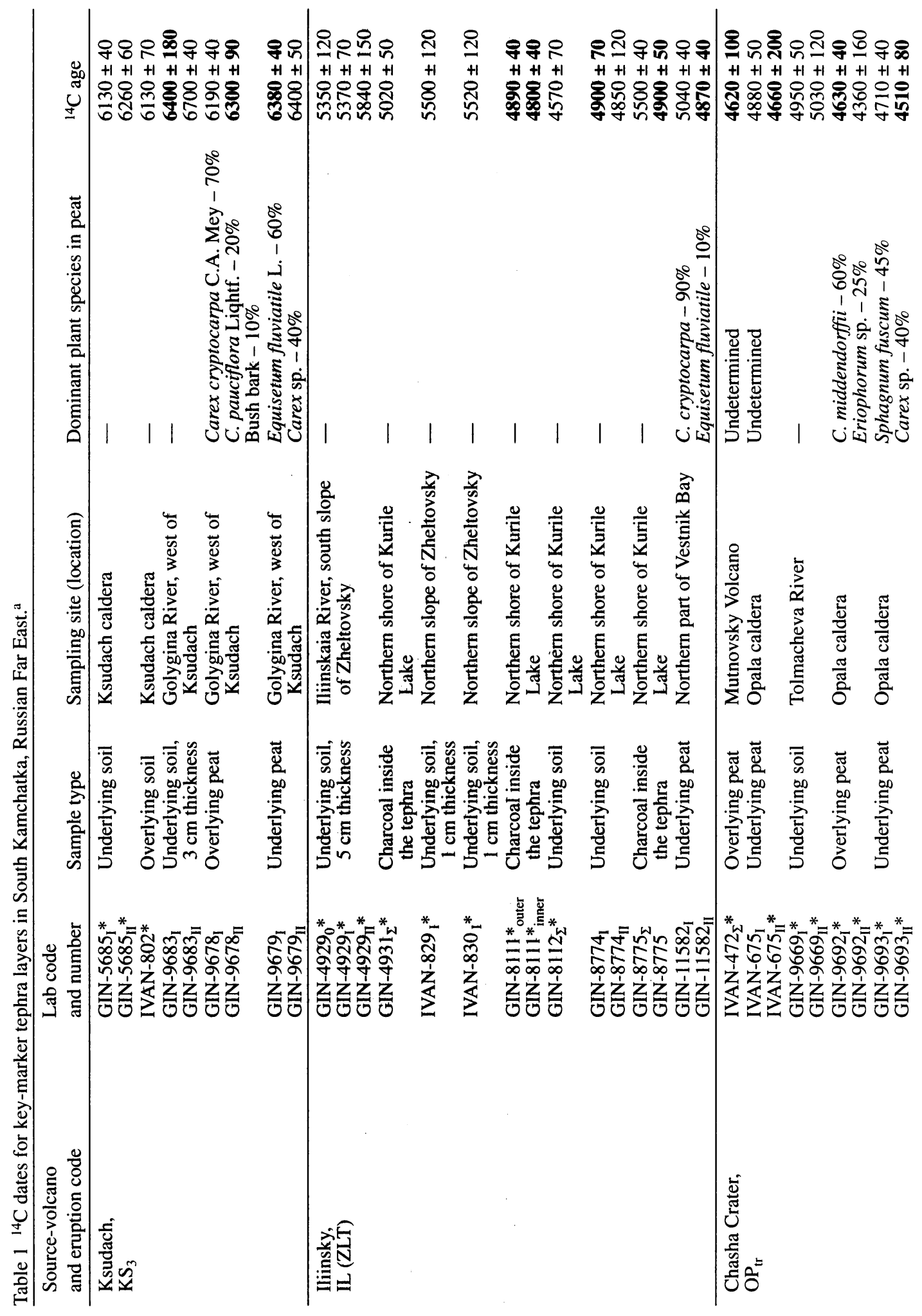




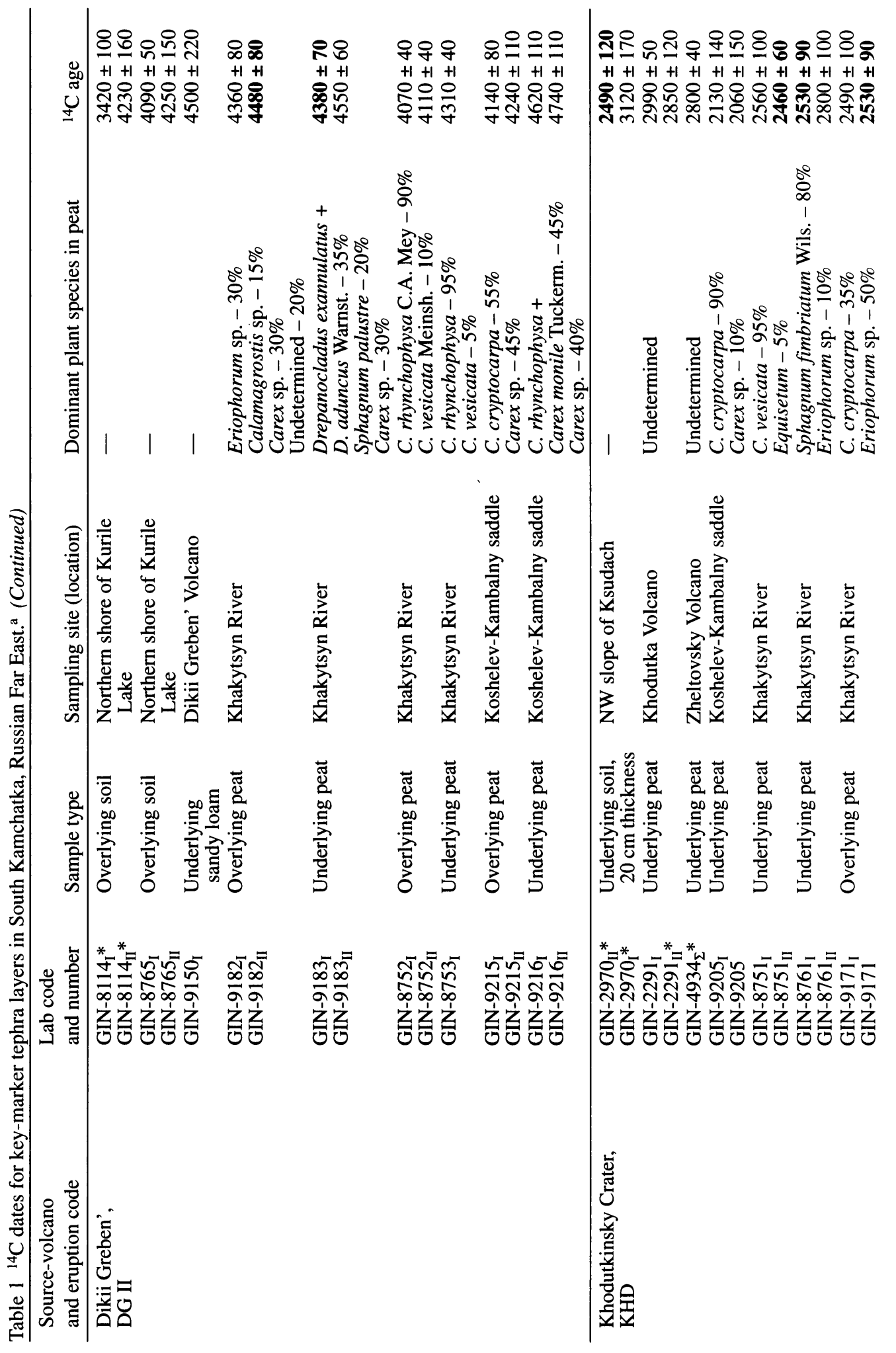




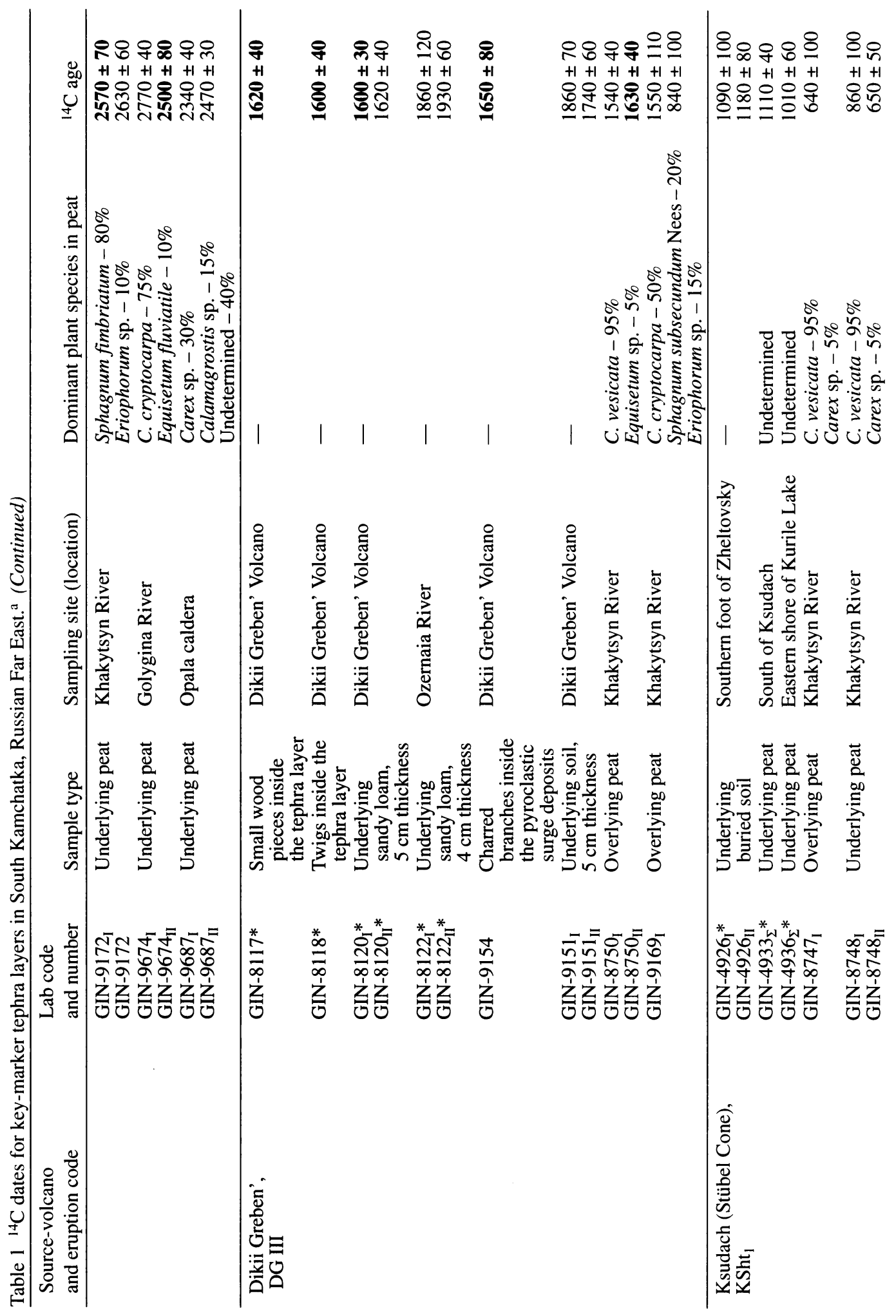




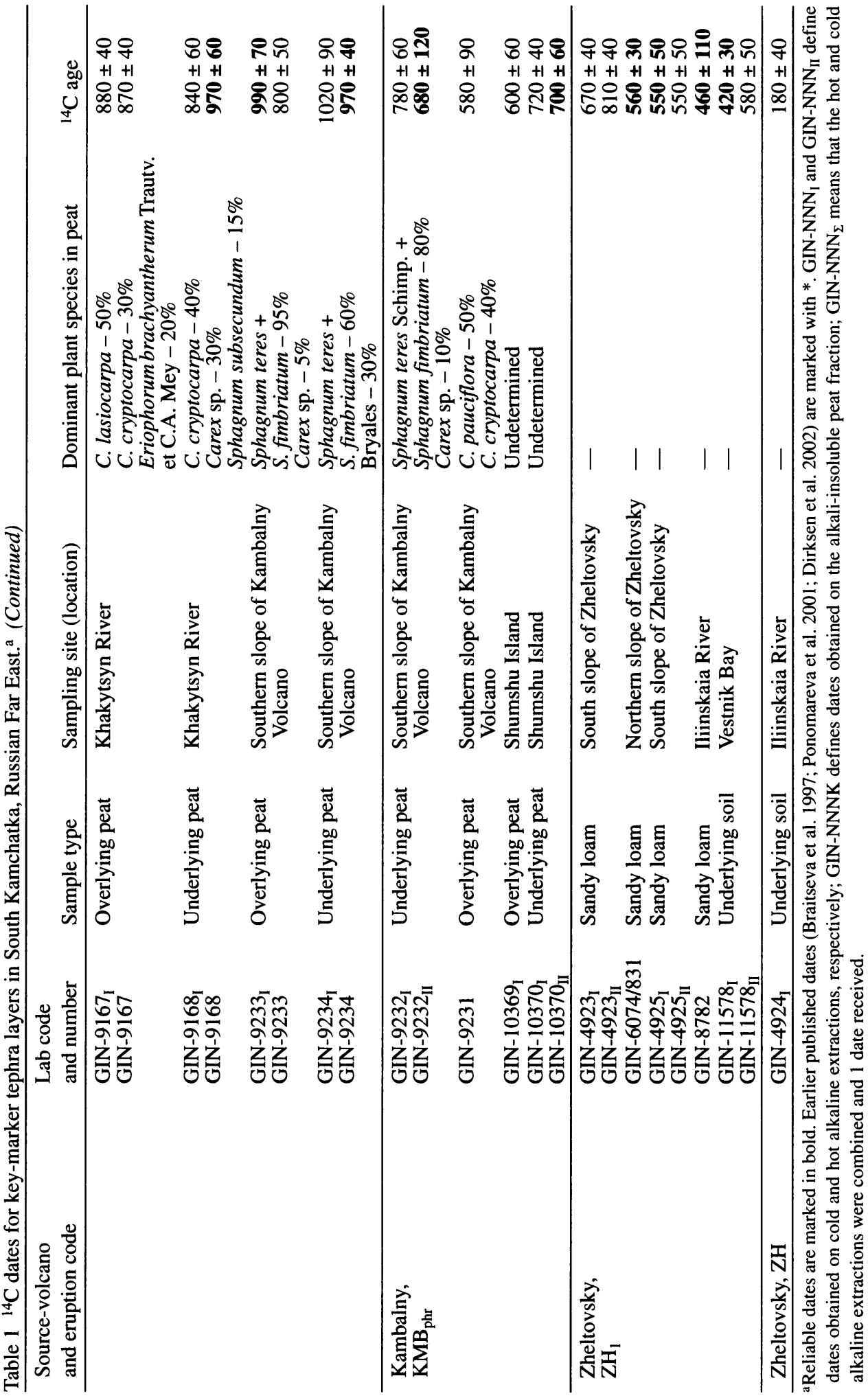


Charcoal and wood are quite rare within the marker tephra horizons of South Kamchatka. Generally, we found only small charred and uncharred twigs buried by ash. We performed a standard AAA pretreatment procedure for both materials. Generally, all the dates appear accurate. There is no fear of inbuilt age due to the short time span of their growth.

In analyzing the whole set of ${ }^{14} \mathrm{C}$ dates, we applied the following criteria:

1. We performed a validity screening, analyzing sample origin, composition, and type of organic matter in each dated sample, excluding "outlier" dates (e.g. dates on redeposited wood, those obtained on peat samples contaminated by long-root sedges from the upper stratigraphic horizons, dates obtained on a single hot alkaline extraction from a thick soil/peat horizon, etc.). All these cases are discussed in the text.

2. After identifying reliable dates, we combined them using the R_Combine function in OxCal v 3.10 (Bronk Ramsey 1995, 2001) and the IntCal04 calibration curve (Reimer et al. 2004). This gave us the mean ${ }^{14} \mathrm{C}$ age for each marker tephra horizon.

3. We publish all ${ }^{14} \mathrm{C}$ determinations to enable other researchers to evaluate our procedure. Calibrated (calendar) ages are not provided since these vary and are frequently updated. Using different programs and approaches yields slightly different calendar ages. We cannot compare directly the ages of marker tephras to any calendar events (e.g. ice cores, dendrochronology, archaeological records, etc.) since the latter are not available for this region.

\section{DATED ERUPTIONS: RESULTS AND DISCUSSION}

We discuss the dated eruptions in chronological order, both in the text and in Tables 1 and 2.

Ksudach Volcano is a shield-like polygenetic edifice composed of lavas and tephra of multiple eruptive centers of various age and morphology. It comprises nested calderas formed during 5 collapse events. A small stratovolcano named Stübel Cone is located in the most recent caldera. The most prominent marker tephra layers from Ksudach are $\mathrm{KS}_{1}, \mathrm{KS}_{2}$, and $\mathrm{KS}_{3}$, related to caldera-forming eruptions, and $\mathrm{KSt}_{1}$ from Stübel Cone (Table 2). Caldera IV formed as a result of 2 large eruptions, $\mathrm{KS}_{3}$ and $\mathrm{KS}_{2}$, closely spaced in time, which produced explosive breccias, pyroclastic flows, and ash falls with a total volume of tephra of about $10-11 \mathrm{~km}^{3}$ (Melekestsev et al. 1996a). The $\mathrm{KS}_{2}$ ash-fall axis was directed to the north, and the $\mathrm{KS}_{3}$ axis to the west (Figure 2A).

The age of this event was earlier roughly estimated as $6300 \mathrm{BP}$ (Volynets et al. 1999). In peat sections (new data), the $\mathrm{KS}_{3}$ tephra layer is separated from $\mathrm{KS}_{2}$, dated to $\sim 6000 \mathrm{BP}$ (Braitseva et al. 1997), by $4-5 \mathrm{~cm}$ of peat. This is why the date $6130 \pm 40 \mathrm{BP}\left(\mathrm{GIN}-5685_{\mathrm{I}}\right)$ under the $\mathrm{KS}_{3}$ tephra is probably too young. This may be explained by the fact that this date was obtained inside the Ksudach calderas, where stratigraphy is complicated. The dates from above and below the peat layers from the individual peat section $(6300 \pm 90$ and $6380 \pm 40 \mathrm{BP})$ were considered to be reliable since the Carex cryptocarpa from the overlying peat had not penetrated through the ash layer. The underlying peat consists mostly of horsepine, and the peat layer overlying sample GIN-9678 consists of Sphagnum mosses. A date of $6400 \pm 180 \mathrm{BP}$ was obtained on the organic-rich soil sample underlying the $\mathrm{KS}_{3}$ tephra and is considered reliable. An average ${ }^{14} \mathrm{C}$ age of $\mathrm{KS}_{3}$ was calculated at $6386 \pm 36 \mathrm{BP}$.

The IL tephra was earlier attributed to the Zheltovsky Volcano and thus coded ZLT (Melekestsev et al. 1996b). Further field investigations have enabled us to instead attribute it to the Iliinsky Volcano and thus recode it IL. Iliinsky Volcano is located in the northeastern part of the Kurile Lake caldera. It started to form soon after the formation of the caldera (Ponomareva et al. 2004) and it is an active center, with the last historic eruption taking place in 1901. This formed a large crater on its eastern slope. The thick cover of Iliinsky pyroclastic deposits is widespread over the Kurile Lake area. The 


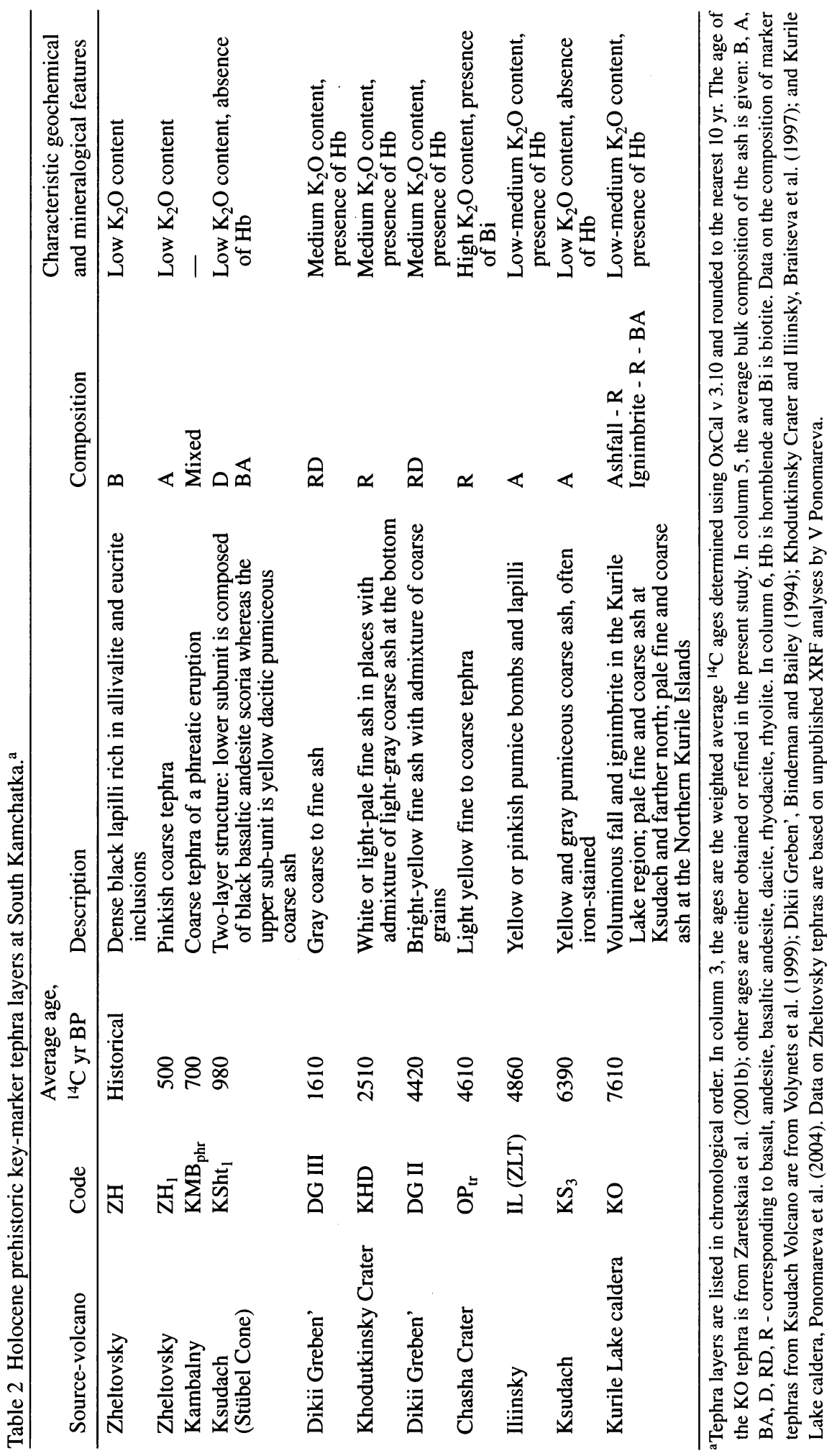


most remarkable bed of yellow pumice bombs and lapilli, informally called "upper coconuts," originated from one of the strongest Iliinsky eruptions. The ash-fall axis was directed to the northeast (Figure 2A).

The IL tephra bed contains charcoal and is underlain by a 2- to 5-cm-thick, organic-rich paleosol, the formation of which may have taken $\sim 1.5 \mathrm{kyr}$ (Ponomareva et al. 2001). The youngest date on this paleosol is $4570 \pm 70 \mathrm{BP}$ (Table 1), which has allowed to estimate the age of the IL tephra at $\sim 4600$ BP (Braitseva et al. 1997). Later, the age was roughly estimated at $\sim 4800$ BP based on a large number of coinciding dates (Ponomareva et al. 2001).

Dates obtained previously on a long-lived paleosol under the IL tephra encompass an age span from $4570 \pm 70$ to $5840 \pm 150 \mathrm{BP}$ (Table 1). Their divergence precludes using them in any averaging to obtain an IL age. In this case, we decided to average the reproducible younger dates from 2 charcoals and underlying peat and soil. The date on peat (GIN-11582) is considered to be reliable in spite of the high long-root sedge content, because the peat layer was capped by $\sim 20 \mathrm{~cm}$ of IL volcanic lapilli, prohibiting penetration of younger roots. The average ${ }^{14} \mathrm{C}$ age for the IL eruption is $4858 \pm$ $24 \mathrm{BP}$.

The $\mathrm{OP}_{\mathrm{tr}}$ tephra was derived from Chasha Crater, located in the central part of the Tolmachev Dol lava plateau (Dirksen et al. 2002). This 450- to 500-m-deep and 1.3-km-wide crater was formed by a single large eruption. The tephra covered an area of $15,000 \mathrm{~km}^{2}$ (Figure $2 \mathrm{~A}$ ), and the total volume of ejected material was estimated as $1.1 \mathrm{~km}^{3}$ (Dirksen et al. 2002). The tephra bed consists of yellow, fine-grained, biotite-bearing ash, which is well identified in the soil-pyroclastic successions. Previously, this marker tephra was attributed to one of the Opala Volcano eruptions, which is why it was coded $\mathrm{OP}_{\mathrm{tr}}$ (Braitseva et al. 1997). Its age was estimated at $4628 \pm 90 \mathrm{BP}$ based on 2 dates (Braitseva et al. 1997). Later, 6 more dates were published but not discussed in any detail (Dirksen et al. 2002). All the dates from the peat above and below the $\mathrm{OP}_{\mathrm{tr}}$ tephra are consistent. We accept the date GIN-9692 ${ }_{\text {I }}$ on a bulk peat sample despite the fact that it contains $60 \%$ of long-root sedge, because the sampled peat layer is covered by Sphagnum papillosum Lindb. peat, so no roots could have penetrated in the lower layer. The dates on the soil seem to be outliers, probably due to longterm accumulation of the organic matter. Thus, an average age of $\mathrm{OP}_{\mathrm{tr}}$ tephra can be estimated at $4609 \pm 33$ BP.

Two important local marker tephras were associated with the Dikii Greben' Volcano (Figure 2A). They are distinctive both visually and geochemically and help to unravel the complicated stratigraphy around Kurile Lake. Dikii Greben' is a dominantly rhyodacitic eruptive center (Bindeman and Bailey 1994) located immediately west of the Kurile Lake caldera. Dikii Greben' consists of a main lava dome (Mt. Nepriyatnaya) and a number of flank domes, occupying an area of $>60 \mathrm{~km}^{2}$ with their lava and pyroclastic flows. Dikii Greben' started to form immediately after the Kurile Lake caldera collapse, and then was active around 4400 BP (DG II) and 1600 BP (DG III) (Ponomareva et al. 2006).

The DGII tephra was dated mostly from peat samples and overlying soils. The date discrepancy is significant. To clear up this case, we analyzed thoroughly the plant composition of dated peats. The samples 9182-9183 (Table 1) appeared the most reliable for dating: they consist of gramineous plants and mosses and do not contain long-root sedges. We excluded all the sedge-rich peat samples from the average. The dates on paleosols are considered as outliers because we consider there to be a gap in soil accumulation (samples 8114 and 8765 ) caused by the eruption. Thus, the average age of the DG II tephra is $4424 \pm 53 \mathrm{BP}$. 
The KHD marker layer is related to Khodutkinsky Crater at the northwestern foot of the Khodutka Volcano (Figure 2B). The total volume of the KHD tephra was estimated at $\sim 1.5 \mathrm{~km}^{3}$ (Melekestsev et al. 1996a). Fall deposits are yellowish coarse ash with pumice lapilli and bombs, and the ash-fall axis was directed to the southwest (Figure 2B). The KHD tephra is an important marker layer for the southernmost part of Kamchatka and the Northern Kurile Islands. Earlier, the KHD tephra was dated to 2800 BP (Braitseva et al. 1997).

The KHD tephra is dated mostly from peat and soil samples (Table 1). Two earlier published dates (Braitseva et al. 1995) proved to be outliers: one of them $\left(\mathrm{GIN}-4934_{\Sigma}\right)$ was obtained on a bulk sample from a thick peat layer, and the other one is older than the youngest reproducible dates on other peats and soils.

New dates were obtained on peat samples. The dates from peat above and beneath the KHD tephra are consistent, so for its age estimation we chose the older overlying and the younger underlying dates. Outliers resulted from a peat sample (GIN-9205) with a high content of C. cryptocarpa, whose roots penetrated through the thin KHD layer from the younger peat horizons. In other cases of long-root sedges occurring in peat samples, the thickness of the KHD layer was $>10 \mathrm{~cm}$, and according to our field observations, the roots could not penetrate through the coarse ash layer (samples GIN-8751, -9171, -9674). Thus, an average ${ }^{14} \mathrm{C}$ age for the KHD tephra is $2509 \pm 32 \mathrm{BP}$. This refined age estimate is in agreement with recently published new dates for the KHD layer. Another support for this estimate is the fact that the KHD layer overlies the tephra from Avachinsky Volcano, which has an age of 2800 BP (Bazanova et al. 2005).

The most recent eruption of Dikii Greben' (DG III) produced a tephra-fall deposit, several lava domes, and a thick lava flow. In addition, east and north of the main dome 2 large lava bodies were formed, the features of which are better explained as originating from the sector collapse of the dome(s) (Ponomareva et al. 2006).

The DG III tephra is well dated from charcoals and wood enclosed within the pyroclastic layers (GIN-8117, -8118, -9154); the dates show a great consistency. Dates from underlying soil and overlying peat, marked in bold in Table 1, confirm this age. Other dates (too young/old) may result from long-root $C$. cryptocarpa in the peat sample or may reflect a long period of sandy loam accumulation. Thus, the average ${ }^{14} \mathrm{C}$ age of DG III is $1612 \pm 18 \mathrm{BP}$.

Stübel Cone started to form about 1600 BP (Melekestsev et al. 1996b). Its products range from basaltic andesite to rhyolite. Fall deposits of the $\mathrm{KSht}_{1}$ eruption are heterogeneous and consist of 2 sub-units: the lower sub-unit is composed of black scoria bombs and lapilli of basaltic andesite, whereas the upper sub-unit comprises white, pink, and yellow dacitic to rhyolitic pumice bombs. The ash-fall axis was directed to the southwest, so the $\mathrm{KSht}_{1}$ is an important marker not only for South Kamchatka but for the Northern Kurile Islands as well (Figure 2C).

We obtained different dates on various samples (Table 1). The most reliable dates are those on peat samples composed of rootless Sphagnum and Bryales mosses (GIN-9233-9234). We selected the younger date from under the $\mathrm{KSht}_{1}$ layer and the older one from above. Dates on bulk samples may reflect the mean ages of a thick soil/peat layer underlying the KSht ${ }_{1}$ tephra. Samples GIN-8747 and -8748 , composed of long-root Carex species ( $C$. vesicata), seem to be contaminated by younger carbon. The average ${ }^{14} \mathrm{C}$ age of the $\mathrm{KSht}_{1}$ marker bed is $975 \pm 35 \mathrm{BP}$.

Kambalny Volcano produced a large phreatic eruption whose tephra were dispersed towards the southernmost part of Kamchatka and the Northern Kurile Islands (Figure 2C). We collected samples for dating from the peat sections near the source and on Shumshu Island. Due to the thickness of this 
tephra layer, and probably due to its chemical composition and resulting change of bog vegetation (Table 1), the gap between "underlying" and "overlying" dates is substantial. Therefore, to estimate the age of this eruption we selected only the "underlying" dates obtained from moss peat. This yielded an average ${ }^{14} \mathrm{C}$ age for $\mathrm{KMB}_{\mathrm{phr}}$ of $696 \pm 54 \mathrm{BP}$.

Zheltovsky Volcano produced a number of explosive eruptions during the Holocene. Tephras of 2 eruptions can be used as markers, especially for studies of tsunami deposits and beach ridges along the Pacific coast. An older eruption $\left(\mathrm{ZH}_{1}\right)$ produced minor fallout, large block-and-ash flow, and related lahars towards the Pacific coast. Its tephra is a pinkish coarse to fine ash. Most of the dates were obtained from sandy loams, and only one from organic-rich soil, all underlying the tephra horizon. Thus, we selected the youngest dates from this data set to estimate the average age of the eruption as $499 \pm 19 \mathrm{BP}$ (Table 1$)$.

The most recent tephra (ZH; Figure 2C, Table 2) immediately underlies the 1907 tephra from Ksudach and was likely related to an eruption in the early 1800 s mentioned in the record (Novograblenov 1932). The date $180 \pm 40 \mathrm{BP}\left(\mathrm{GIN}-4924_{\mathrm{I}}\right)$ on the underlying soil does not contradict this conclusion. This tephra consists of heavy sub-rounded basaltic lapilli rich in allivalite and eucrite inclusions.

\section{CONCLUSIONS}

In analyzing the origin of ${ }^{14} \mathrm{C}$ samples, their composition, and the stratigraphic relationships with the dated marker tephra layers, we carefully analyzed the most reliable measurements from large data sets to add precision to the ${ }^{14} \mathrm{C}$ age of a series of volcanic events within the Kamchatka Peninsula.

Dated key-marker tephra horizons record the largest explosive eruptions of South Kamchatka volcanoes and can be used for dating both volcanic and nonvolcanic landforms and deposits (e.g. paleotsunami sands; landslides; marine, lacustrine, and river terraces; beach ridges; Holocene moraines; etc.). They also provide a useful tool for paleoclimatic research based on peat bog and lake core studies.

\section{ACKNOWLEDGMENTS}

The research described in this paper was supported in part by the Russian Foundation for Basic Research (grants 05-05-64776 and 06-05-64960), the Russian Academy of Sciences Program "Environmental and Climate Change," and the Council for Grants of the President of Russian Federation (MK-1741.2005.5). Field work was funded by grants 5663-96, 5926-97, 6215-98, 6543-99, and 7189-02 from the National Geographic Society and NSF grant EAR-0125787 to Joanne Bourgeois.

\section{REFERENCES}

Alexeev Yu E. 1996. Sedges. Moscow: Argus. 252 p. In Russian.

Anderson PM, Lozhkin AV, Belaya BV. 1998. Younger Dryas in western Beringia (northeastern Siberia). In: Simakov KV, editor. Environmental Changes in Beringia During the Quaternary. Magadan: North East Interdisciplinary Research Institute, Far East Branch, Russian Academy of Sciences. p 28-44. In Russian.

Bazanova LI, Braitseva OA, Dirksen OV, Sulerzhitsky LD, Danhara T. 2005. Tephra layers from the largest Holocene eruptions along the Ust-Bolsheretsk - Petropavlovsk-Kamchatsky traverse: sources, chronology, occurrence. Volcanology and Seismology 6:30-46. In Russian.

Bindeman IN, Bailey JC. 1994. A model of reverse differentiation at Dikii Greben' Volcano, Kamchatka: progressive basic magma vesiculation in a silicic magma chamber. Contributions to Mineralogy and Petrology 117(3):263-78.

Braitseva OA, Sulerzhitsky LD, Litasova SN, Melekestsev IV, Ponomareva VV. 1993. Radiocarbon dating and tephrochronology in Kamchatka. Radiocarbon 35(3):463-76.

Braitseva OA, Melekestsev IV, Ponomareva VV, Sul- 
erzhitsky LD. 1995. Ages of calderas, large explosive craters and active volcanoes in the Kuril-Kamchatka region, Russia. Bulletin of Volcanology 57(6):383402.

Braitseva OA, Ponomareva VV, Sulerzhitsky LD, Melekestsev IV, Bailey J. 1997. Holocene key-marker tephra layers in Kamchatka, Russia. Quaternary Research 47(2): 125-39.

Bronk Ramsey C. 1995. Radiocarbon calibration and analysis of stratigraphy: the OxCal program. Radiocarbon 37(2):425-30.

Bronk Ramsey C. 2001. Development of the radiocarbon program. Radiocarbon 43(2A):355-63.

Dirksen OV, Ponomareva VV, Sulerzhitsky LD. 2002. Eruption from Chasha Crater - a unique large silicic eruption at a monogenetic basaltic lava field. Volcanology and Seismology 5:3-10. In Russian.

Gorbarenko SA, Nürnberg D, Derkachev AN, Astakhov AS, Southon JR, Kaiser A. 2002. Magnetostratigraphy and tephrochronology of the Upper Quaternary sediments in the Okhotsk Sea: implication of terrigenous, volcanogenic and biogenic matter supply. Marine $G e$ ology 183(1-4):107-29.

Hotes S, Poschlod P, Takahashi H, Grootjans AP, Adema E. 2004. Effects of tephra deposition on mire vegetation: a field experiment in Hokkaido, Japan. Journal of Ecology 92(4):624-34.

Melekestsev IV, Braitseva OA, Bazanova LI, Ponomareva VV, Sulerzhitsky LD. 1996a. A particular type of catastrophic explosive eruption with reference to the Holocene subcaldera eruptions at Khangar, Khodutka Maar, and Baranii Amphitheater volcanoes in Kamchatka. Volcanology and Seismology 18:135-60. In Russian.

Melekestsev IV, Braitseva OA, Ponomareva VV, Sulerzhitsky LD. 1996b. Holocene catastrophic calderaforming eruptions of Ksudach Volcano, Kamchatka. Volcanology and Seismology 17:395-421. In Russian.

Novograblenov PT. 1932. A catalogue of volcanoes of Kamchatka. Isvestiya Gosudarstvennogo Geograficheskogo Obshestva XIY(1):88-99. In Russian.

Ponomareva VV, Sulerzhitsky LD, Dirksen OV, Zaretskaia NE. 2001. Holocene paleosols as records of intervals of volcanic quiescence in the Kuril Lake region,
South Kamchatka. In: Juvigné E, Raynal JP, editors. Tephras, Chronology and Archaeology. Les dossiers de l'Archéo-Logie $n^{\circ} 1$. Goudet: CDERAD Press. p 91-100.

Ponomareva VV, Kyle PR, Melekestsev IV, Rinkleff PG, Dirksen OV, Sulerzhitsky LD, Zaretskaia NE, Rourke R. 2004. The $7600\left({ }^{14} \mathrm{C}\right)$ year BP Kurile Lake calderaforming eruption, Kamchatka, Russia: stratigraphy and field relationships. Journal of Volcanology and Geothermal Research 136(3-4):199-222.

Ponomareva VV, Melekestsev IV, Dirksen OV. 2006. Sector collapses and large landslides on Late PleistoceneHolocene volcanoes in Kamchatka, Russia. Journal of Volcanology and Geothermal Research 158(1-2): 117-38.

Reimer PJ, Baillie MGL, Bard E, Bayliss A, Beck JW, Bertrand CJH, Blackwell PG, Buck CE, Burr GS, Cutler KB, Damon PE, Edwards RL, Fairbanks RG, Friedrich M, Guilderson TP, Hogg AG, Hughen KA, Kromer B, McCormac G, Manning S, Bronk Ramsey C, Reimer RW, Remmele S, Southon JR, Stuiver M, Talamo S, Taylor FW, van der Plicht J, Weyhenmeyer CE. 2004. IntCal04 terrestrial radiocarbon age calibration, 0-26 cal kyr BP. Radiocarbon 46(3): 1029-58.

Sulerzhitsky LD. 1971. Radiocarbon dating of volcanoes. Bulletin of Volcanology 35(1):85-94.

Volynets ON, Ponomareva VV, Braitseva OA, Melekestsev IV, Chen CH. 1999. Holocene eruptive history of Ksudach volcanic massif, South Kamchatka: evolution of a large magmatic chamber. Journal of Volcanology and Geothermal Research 91(1):23-42.

Zaretskaia NE, Uspenskaia ON. 2001. Volcanic influence on Holocene peat bog vegetation [abstract]. Abstracts of the International Conference "Plants and Volcanoes.” Petropavlovsk-Kamchatsky. p 25.

Zaretskaia NE, Ponomareva VV, Sulerzhitsky LD, Zhilin MG. 2001a. Radiocarbon studies of peat bogs: an investigation of South Kamchatka volcanoes and Upper Volga archeological sites. Radiocarbon 43(2B):57180.

Zaretskaia NE, Ponomareva VV, Sulerzhitsky LD, Dirksen OV. 2001b. Radiocarbon dating of the Kurile Lake caldera eruption (South Kamchatka, Russia). Geochronometria 20:95-102. 